\title{
Ksiądz Benedykt Chmielowski jako uczony barokowy
}

Maria Wichowa 


\section{Maria Wichowa}

\section{Ksiądz Benedykt Chmielowski jako uczony barokowy}

\section{Stan encyklopedyzmu barokowego}

\section{Idea pansofii w nauce europejskiej XVII w.}

Na Nowe Ateny księdza Benedykta Chmielowskiego złożyły się dwa tomy, z których pierwszy wyszedł w 1745 r. we Lwowie w oficynie Golczewskiego, drugi zaś rok później w tamtejszej drukarni jezuitów. Wydanie następne pochodzi z lat 1754-1756, a zawiera, obok przedruku tomów 1-2, tzw. suplement, czyli tomy 3 i 4.

Dzieło ukazało się więc u schyłku czasów saskich i nie miało dobrej opinii wśród uczonych. Przez długie dwa wieki wydawano o tej książce bardzo surowe sądy. Józef Kallenbach okreslił ja jako „straszliwe kuriozum encyklopedycznej niewiedzy, w której nie wiadomo co bardziej podziwiać, czy naiwność kompilatora, czy jego pracowitość, czy wreszcie dokładność w przytaczaniu rzekomych źródeł" ${ }^{1}$. Encyklopedia Chmielowskiego w intencjach wielu badaczy (Kallenbach, Wilhelm Feldman, Julian Krzyżanowski) miała stanowić dowód upadku kultury polskiej u progu epoki oświecenia. Tymczasem należy na nią spojrzeć jako na dużej rangi wytwór tej kultury, na dokument obrazujący stan nauki czasów, w których powstała. Bowiem każda encyklopedia wyraża ducha swej epoki, jest odbiciem mentalności swego twórcy czy też twórców, wyrasta z określonych tradycji i środowiska kulturalnego,

' J. Kallenbach, Przyczyny upadku Polski, [w:] Czasy saskie. Wybór źródet, opr. J. Feldman, Kraków 1928 (BN I 110). 
stanowi obraz tendencji intelektualnych znamiennych dla zainteresowań i warsztatu autora, odzwierciedlenie jego światopoglądu i orientacji naukowej.

Zadaniem tego artykułu jest pokazanie Nowych Aten jako dzieła ściśle osadzonego w tradycji nauki barokowej, która na terenie Rzeczypospolitej wydała wiele wybitnych indywidualności, wśród nich znakomitego leksykografa Grzegorza Knapskiego, profesora Akademii Krakowskicj Sebastiana Petrycego, uczonego gdańskiego Bartłomicja Keckermanna; w Lesznie działał słynny pedagog czeski Jan Amos Komeński. Wymienieni uczeni w większości uważali, że wybitny umysł ludzki jest w stanie ogarnąć całość dostępnej mu wiedzy, a sami prowadzili działalność naukową w różnych dyscyplinach równocześnie, np. w naukach humanistycznych i przyrodniczych. Wymicnić tu należy Jana Adamandego Kochańskiego, Sebastiana Petrycego, Jana Jonstona, a także Bartłomieja Keckermanna ${ }^{2}$. Wspominany już Komeński opowiadał się za koncepcją uniwersalizmu nauki i za pansofią, która miała stanowić próbę ujęcia we właściwym, wręcz idealnym skrócie, aby nic uronić niczcgo ważnego, całości wiedzy zdobytej przez ludzkość3. Jesteśmy wiçc u progu barokowego encyklopedyzmu, dla którego pansofia była właściwym kierunkiem działania. Pojęcie to wyjaśniał Komeński w następujacy sposób:

Wszechwiedza ludzka to ujęcie całej mądrości, jaka przypadła w udziale człowiekowi. Nazywamy ją pansofią, to jest wszechwiedzą, ponicważ w ten sposób podkreślamy, aby wszyscy ludzie uczyli się być mądrymi w każdym zakresie i w pełni. To, że wszyscy ludzic mają być mądrzy, znaczy, że nikt, kto się urodził człowiekicm, nie może być pozbawiony tego wspólnego światła mądrości ${ }^{4}$.

Jak widać, Komeński dążył do tego, aby człowiek-uczony zdołał ogarnąć swym umysłem wszystkie zagadki świata, nie do końca jasnego, raczej nie do końca zrozumiałego, i jako przeciwwagę przedstawić niezbitą pewność ustalonych systemów wiedzy:

Oby jednak Bóg otworzył człowiekowi oczy ducha, aby człowick mógł przcniknąć związek rzeczy i ukazać go innym ludziom! W zarysie chrześcijańskiej pansofii, jeśli Bóg pozwoli, dam próbę mojego doświadczenia, z pokorną nadzieją, żc Bóg, za pośrednictwem innych, ujawni kiedyś więcej takich prób ${ }^{5}$.

Zatem istniejąca wiedza może być uformowana w jednolitą całość, w jakąś wszechnaukę, zamkniętą w dziele encyklopedycznym, chociaż powstania wielkiej uniwersalnej encyklopedii twórca tej koncepcji nie doczekał.

Słowa Komeńskicgo wyrażają wiarę w „organicznąjedność całości wiedzy” "w możliwość wypracowania wiedzy uniwersalnej. Wiara ta była udziałem licznych środowisk naukowych

${ }^{2}$ Zob. M. Iłowiecki, Dzicje nauki polskiej, Warszawa 1981, s. 98-102.

${ }^{3}$ Zob. E. Angyal, Śutiat stowiańskicgo baroku, tł. J. Prokopiuk, sł. wst. J. Sokołowska, Warszawa 1972, s. 190.

+ Cyt. za: J. Olkiewicz, Od A do Z czyli o encyklopediach i encyklopedystach, Warszawa 1988, s. 49.

s Tamże, s. 151.

${ }^{6}$ C. Vasoli, Encykopedyzm w XVII wicku, Warszawa 1989, s. 5. 
w XVII w. Jej metaforycznym obrazem było określenie arbor scientiarum — drzewo wiedzy. Uczeni głosili idę̨ stworzenia encyklopedycznego systemu wiedzy uniwersalnej, który byłby zarazem systemem powszechnym i skierowanym ku odnowie człowieka. Miałaby to być wiedza przedstawiona przystępnie, zaprezentowana w całości, tzn. pokazująca wszystkie dziedziny nauki i sztuki, w usystematyzowanej strukturze. Uczeni tamtych czasów „uważali encyklopedię za istotne narzędzie nieograniczonego postępu naukowego, moralnego i społecznego" ${ }^{7}$. Czy wobec tego taki cel — ogarnięcie wicdzy z różnych dziedzin i uprzystępienie jej szerokim rzeszom odbiorców, jak równicż zamiar opracowania encyklopedii i jego urzeczywistnienie według koncepcji nauki barokowej - powinno być argumentem przeciwko Chmielowskiemu? Trzeba również wziąć pod uwagę, żc dzieło wyszło spod pióra amatora, a nic zawodowego uczonego. Mimo to dziekan rohatyński dobrze orientował sic̨ w głównych założeniach ówczesnego encyklopedyzmu. Aprobował przekonanie, że wiedza powinna być użyteczna, przedstawione poglądy mają być poddanc krytycznej analizic i ocenic, twórca encyklopedii powinien też kierować się praktycyzmem, troską o korzyści użytkownika dzicła.

Ówcześni uczeni wręcz byli przekonani, iż opracowywanie kompendiów encyklopedycznych jest niezbędne, aby popularyzować wiedzę naukową z różnych dziedzin. Głęboko wicrzyli,

że wszyscy powinni poznać przynajmniej podstawy nieodzownych nauk, jak prawo czy medycyna, oraz żc nie powinny być im obce zasady chemii, astrologii i magii naturalnej choćby po to, aby uniknąć wprowadzenia w błąd (...) przez autorów horoskopów, wróżbitów i fałszywych magów. W końcu także sztuki mechaniczne, rolnictwo i architektura są (...) integralnymi częściami wiedzy, niezbędnymi dla każdego, kto chce działać ze znajomością rzcczy i pewnością, jako że nie można posiadać nauki bez sztuki ani sztuk bez nauk. Wystarczy tylko znać ich podstawowe i „przewodnie” pojęcia, należycic uporządkowane zgodnie $z$ ich racjonalnym i metodycznym ladem ${ }^{8}$.

Taki też był cel pracy Chmielowskiego. Intencją tego domorosłego uczoncgo było dążenic do prawdy, zgłc̨bienie jej i udostępnienic odbiorcy dzieła. W przedmowie Do czytchika wyjaśniał:

Musiałbyś wielkie przewracać volumina, skupować biblijoteki, a tu masz bez pracy multa scienda [liczne wiadomości], które gotowe czytając, zważ, że non iacet in molli veneranda Scientia lecto [czcigodna Wiedza nic leży na miękkim łożu].

Opracowanie Nowych Aten wymagało wielkiego wysiłku. Aż podziw bierze, że tę gigantyczną pracę wykonał jeden człowiek. Przed przystąpicniem do pisania musiał podjąć ważkie decyzje co do kształtu dzieła i jego układu. W tym wypadku kierował się rozwiązaniami wypracowanymi przez tradycję tego gatunku piśmiennictwa.

7 Tamże, s. 7.

\& Tamże, s. 49. 


\section{Koncepcja encykopedii Chmielowskiego na tle tradycji i praktyki współczesnej pisarzowi}

Jak wiadomo, encyklopedyzm narodził się w starożytnej Grecji i z powodzeniem rozwijał się w Rzymie, następnie w średniowieczu i w kolejnych epokach kultury europejskiej. Pojęcie encyklopedia ma też grecką proweniencję. Zwrot enkyklios paideia znaczy „tworzący całkowity krąg wykształcenia”. Nie jest to odległe od barokowej idei pansofii, dążącej do ogarnięcia pełni wiedzy i uformowania z niej jednolitej całości.

Kolejny po Chmielowskim polski encyklopedysta, Ignacy Krasicki, wyjaśniał istotę takicgo dzieła następująco:

Encyklopedyja, termin znaczący związek wiadomości [podkr M. W.]. W tłumaczeniu powszechnym znaczy zbiór nauk [podkr M. W.]. Pod tym tytułem wyszedł dykcyjonarz zawierający w sobie opisy nauk i kunsztów ${ }^{9}$.

Mowa oczywiście o dziele Diderota.

Tak więc czytelnik Nowych Aten „bez pracy” otrzymuje multa scienda, a to przecież nic innego, tylko ów zbiór nauk, zbiór potrzebniejszych wiadomości, by użyć słów tytułu dzieła Krasickiego. Zatem Chmiclowski jest pod tym względem dzieckiem swoich czasów, ani „zapóźniony”, ani „nowoczesny”. Epoka krytycyzmu oświeceniowego dopiero nadchodziła.

WXVII w. dominowały tzw. encyklopedie powszechne, inaczcj uniwersalne, obcjmujące systematycznie ułożony zbiór informacji z wszystkich dziedzin wiedzy, ale pojawiały się także mniejsze encyklopedie specjalistyczne. Od starożytności, chociaż znany już był układ alfabetyczny materiału, przeważał porządek systematyczny, według zagadnień. Taki kształt mają Nowe Ateny albo akademija wszelkiej sciencyi petna, na różne tytuty jak na classes podzielona (...), co w tytule uwypuklił ich twórca. Układ systematyczny obowiązywał w encyklopediach aż po wiek XVII, kicdy to sporadycznie zaczęły się pojawiać dzieła z hasłami w układzie abecadłowym, natomiast w XVIII w. dzięki Encyklopedii Diderota porządek alfabetyczny stał się bardzicj powszechny.

Opracowując swe dzieło Chmielowski szukał oparcia w pracach autorów o nickwestionowanych autorytetach. Wpływ nauki barokowej jest znowu silnie obecny w tym właśnie aspekcie. Widać mianowicic po sposobie gromadzenia materiału, że Chmielowski jest zwolennikiem barokowej teorii imitacji. Wzorami pisarskimi są dla niego autorzy starożytni, których powinien naśladować. Imitacja w XVII w. skłania się ku „luźnym ekscerptom i ewokuje mozaikowo mieniącą się paletę literackich remimiscencji" ${ }^{10}$. Pisarze niekoniecznie musieli sięgać bezpośrednio do źródeł, mogli czerpać z autorów nowych, opierających swe dzieła na starożytnych.

\footnotetext{
${ }^{9}$ Zbiór potrzebniejszych wiadomości porządkiem alfabetu utożonych, t. 1, Warszawa i Lwów 1781, s. 264.

${ }^{10}$ B. Otwinowska, Imitacja, [w:] Stownik literatury staropolskicj (średniowiecze - renesans - barok), red. T. Michatowska, Wrocław 1990, s. 301.
} 
Odbicie ducha epoki, w której powstały Nowe Ateny, widać również w sposobie gromadzenia owej sciencyi. Chmielowski występuje jako zwolennik barokowej teorii imitacji, także w zakresie naukowych autorytetów. Wyjaśniał czytelnikowi swoje stanowisko następująco:

Każdą rzecz próbuję powagą autorów, mając w tym purpurata rzymskiego Baronijusza przestrogę: Quod a recentiore authore de rebus antiquis sine alicuius vetustrioris authoritate profertur, contemnitur [nowszy autor jest miany za nic, gdy przedstawia coś z dawnej przeszłości nie wsparty powagą dawno uznanych pisarzy].

(Do czytelnika)

Autor encyklopedii jest więc kompilatorem, który zdobywszy ogromną wiedzę, rzetelnie ją opracowuje z powołaniem się na poważne źródła. Gdy wypowiada się jako historyk, sięga do wszystkich dostępnych mu materiałów i przekazów, nie pomijając poezji. Z wielką powagą i szacunkiem odnosi się do starożytnych autorytetów, ale gdy nie aprobuje ich punktu widzenia, dystansuje się od nich. „Normy literackie czerpane dawniej wprost ze wzorów antycznych przejmuje się w tym stuleciu za pośrednictwem reguł retorycznych i gatunkowych, zawierzając nie tyle prestiżowi dawnych mistrzów, ile własnemu «dowcipowi». Ustala się także pewien kanon wzorców nowych (...)"11.

Mówiąc o historii starożytnej, Chmielowski sięga do dzieła Pliniusza Starszego (Historia naturalna), do historyków: Liwiusza czy Dionizego z Halikarnasu, do tekstów poetyckich: Owidiusza, Propercjusza, Marcjalisa. Zauważmy, że erudycja naszego encyklopedysty musiała być bardzo rozległa i rzetelna, penetrował i opanował on różne dziedziny wiedzy, a więc w jakiejś mierze przyswoił sobie znaczny obszar wszechwiedzy, o której pisał Komeński, a także potrafił ją opanować, usystematyzować i przekazać czytelnikowi. Brak mu było doświadczenia naukowego, czasem ujawniał się w nim amator, ale zarazem twórca niezwykle rzetelnie traktujący przyjęte na sicbie obowiązki informowania czytelnika swego dzieła, a w ramach kompilacji widać pewną samodzielność badawczą.

Zatem ocenić wypada, jaką wartość miały przekazywane wiadomości?

\section{Wartość naukowa dzieła Chmielowskiego}

W przedmowie Do czytelnika pisarz podkreślił, że dbał o samodzielność opracowania materiału i odpowiedni poziom źródeł, do których sięgał.

Nie z szkolnych szpargałów, które częściej pod placki do piekarni niż do mądrej Kleantesa zdarzają się latarni, ani też z cudzej, jak inni, zawarłem pracy, za czym nie boję się Zoila okrzyknienia: Dicit tibi tua pagina, fur es [mówi ci twoja karta: jesteś złodziej]. Lecz kilkaset autorów od deszczki do deszczki przeczytawszy,

"Tamże. 
tu i ówdzie pożyczając, to skupując, na ich fundamencie te Nowe dla ciebie, czytelniku, wystawiłem Ateny. Cokolwiek mądrego, ciekawego, do erudycyi służącego wyczerpnąłem, to sine invidia [bez zazdrości] na theatrum moich Aten wystawiam curiosis [ciekawym].

(Do czytelnika)

Zatem Chmielowski uczciwie gromadził („pożyczał, skupował”) zawarte w studiowanych dziełach wiadomości, podając ich lokalizację, za kryterium ich doboru przyjmując, aby były przydatne „do erudycyi” a przy tym mądre i zaciekawiające. Wydaje się, że było to również kryterium oczekiwań czytelnika. W pierwotnym zamiarze autora Nowych Aten odbiorca dzieła miał być człowiekiem wykształconym i wymagającym. Ta „polska księga” przeznaczona była nie dla „formalnych idiotów i infimistów” (czyli uczniów klasy początkowej, niższej), ale dla tych, którzy „w wyższych szkołach, w dworskiej polityce i nad księgami bawią się sedenteryją" (Do czytelnika). Tak więc, zdaniem pisarza, to jego opusculum (dziełko) będzie źródłem mądrości zarówno dla duchownego, jak i polityka, a także uczącego się. Ten poradnik (promptuarium) da im wszystkim owoc bez pracy, gotowe światło wiedzy, aby mieli z czym wystąpić na publicznych mównicach, ambonach, miejscach dysput. Zatem jest to ambitny program oświecania umysłów, szerzenia postępu. Z wyraźną dezaprobatą pisarz mówi o części czytelników, którzy z pewnością nie sięgną po Ateny, gdyż nie ma tam romansów, żywotów świętych ni przykładów (egzemplów) umoralniających, a właśnie tak tandetnego pokarmu duchowego potrzebują. Widać znaczne ambicje uczonego autora. $Z$ drugiej strony nie jest badaczem przyrzucającym nauce jakieś nowe odkrycia, ale też nie obawia się zarzutu, że o jego dziele może ktoś powiedzieć „nic nowego pod słońcem”. A więc przedstawia nie tyle nowe wiadomości, co „stare” na nowo zinterpretowane i stosownie opracowane. Chmielowski w swym dziele nieraz zdradza czytelnikowi, jaką metodą opracował relacjonowane zagadnienie.

Pierwszy bazylika albo Kościoł św. Piotra in monte Vaticano [na wzgórzu Watykańskim]. Opisał go w wielkim bardzo tomie łacińskim i włoskim kawaler Karol Fontana, architekt sławny, z ktorego ja essentialia tylko tagendo [czerpiąc tylko to, co najistotniejsze], odrysuję króciusieńko czytelnikowi mojemu.

Jak widać, aby zrobić krótką notatkę, uczony zapoznał się z ogromnym opracowaniem i przyrządził z niego esencjonalny wyciąg. Sięgał do źródeł pierwszorzędnych, zdobywał wiedzę rozległą i rzetelną. Nikt mu nie powie, że przepisał żywcem z istniejących dzicł, bo w istocie na nowo opracował stosowny fragment swego kompendium. Posiadał własne zbiory książek, a także „z biblijotek różne kredytowane”, w których copiosam eruditionem powziąwszy, napisał encyklopedię.

Chmielowski był samorodnym talentem, przygotowanie naukowe miał raczej skromne. Jednak ten absolwent lwowskiego kolegium jezuickiego, a następnie lwowskiego semina- 
rium katedralnego miał wysokie aspiracje intelektualne. Nie odbył co prawda studiów naukowych uniwersyteckich, nie podróżował po świecie, ale prezentował się dobrze jako człowick światły. Był proboszczem prowincjonalnym, lecz człowiekiem wybitnym, nie jednym z wielu. Jako domorosły uczony współpracował z biskupem Józefem Andrzejem Załuskim, otrzymywał od niego rady co do doboru źródeł i pomoc biblioteczną oraz uznanie dla przedsięwziętego dzieła.

Celem Chmielowskiego było więc stworzyć encyklopedię — poradnik o nastawieniu dydaktycznym i utylitarnym. Tytuł pierwszy wtórej części dzieła tę postawę eksponuje:

Nowy peregrynant starego świata lustrator, domator wszędziebylski alias essencyjalne i osobliwe scienda o państwach, królestwach, księstwach, prowincyjach, miastach wiclkich cum suis mirabilibus [ $\mathrm{z}$ ich podziwu godnymi miejscami] krótko skompendyjowanc ex probatissimis authoribus multis [z licznych wypróbowanych autorów].

W zamyśle Chmielowskiego miał to być rodzaj przewodnika po opisywanych krajach dla wybierającego się w podróż. Autor zadbał, aby peregrynanci otrzymali szczegółową informację o zwiedzanym państwie i instrukcję, jaki mają wyznaczyć sobic cel wyprawy, a więc poznać kraj, zdobyć o nim wiedzę praktyczną, wynieść mądrość życiową i doświadczenie, nauczyć się rozróżniać dobro i zło, przyswajać pierwsze, odrzucać drugie. Opracował nawet tabelkę, z której podróżnicy mają uzyskać informację i otrzymać instrukcję ułatwiającą podróżowanie. Z wyprawy po świecie należy przywieźć do ojczyzny nie tylko wrażenia turystyczne, ale i korzyści duchowe. W tej partii encyklopedii Chmielowski, w istocie rzeczy kompilator, miał wyraźne ambicje naukowe. Występował jako historyk - badacz dawnych i współczesnych źródeł, którc zgromadził obficie, a opracowując je wykazywał sic̨ znaczną samodzielnością dociekań.

Czytelnik dzieła Chmielowskiego wynosił rzetelną, rozległą wiedzę o opisywanych krajach. Autor bardzo skrupulatnie opracował wiadomości historyczne i geograficzne, pilnie zważał na to,

jaka w zwiedzanym państwie acryja, pozycyja, obfitość, jaka długość i szcrokość granic? Jak dawne to królestwo, ex quibus initiis [z jakich początków] powstało lub upadło? Co tam za wojny i eventa [zdarzenia] trafiały się?

Informacje historyczne i geograficzne są ściśle ze sobą złączone. Wiadomości geograficzne podawał dokładnie według źródeł, z których korzystał. Starał sic̨ wskazać wielkość powierzchni, długość i szerokość geograficzną, większe miasta, rzeki, góry itp. Zarazem zamieszczał wzmianki historyczne odnoszące się do opisywanego terenu.

Jako historyk reprezentował sarmacki punkt widzenia na przeszłość. Historiografia w jego rozumieniu miała stawiać sobie cele dydaktyczne, zaś w pojęciu staropolskiej szlachty, a także uczonych stanowiła ważny czynnik wychowawczy. Stanisław Źółkiewski w testamen- 
cie zwracał się do syna ze słowami: „Historyki pilnie czytaj” i wyjaśniał, jakie sam wyniósł ogromne korzyści moralne ze studiowania dzieł antycznych dziejopisów. Sam też chwytał za pióro, aby utrwalić obraz wojny moskiewskiej. Chmielowski myślał podobnie, okazał się tradycjonalistą w rozumieniu historii. Sarmacka kultura objawiała rozmiłowanie w przeszłości, zwłaszcza w dziejach swojego narodu. Autor Nowych Aten okazywał afirmację przeszłości w ogóle. Prezentowal stanowisko czasami bezkrytyczne lub może pewną bezradność w obiektywnym ocenianiu wydarzeń rekonstruowanych z gąszczu faktów, opisywanych na podstawie wielu źródeł. Z powag̨a rzetelnego uczonego powoływał się na legendy, potwierdzał ich wiarygodność, stawiał na równi ze źródłami o niekwestionowanej wartości historycznej. Czasem jednak zachowywał rezerwę wobec podawanych faktów, relacjonował je bez oceny ich wartości źródłowej lub wręcz dystansował się zastrzegając, że on tylko przedstawia cudze poglądy. Jest jeszcze jedna godna uwagi cecha Chmielowskiego-historyka. W sposób charakterystyczny dla kultury sarmackiej rozumiał relacje między przeszłością a dobą mu współczesną. „W tradycyjnym modelu sarmackiego historyzmu przeszłość była wszechobecna w teraźniejszości jako tradycja i potwierdzająca ją historia"12. Historia stanowiła dla niego źródło, a może nawet zbiór przykładów o wymowie moralizatorskiej, szczególnie akcentowana i ceniona pod tym względem była historia święta. Tu bliski jest w rozumicniu historii wybitnemu uczonemu doby baroku, Szymonowi Starowolskiemu, który w rozprawie Penu historicum poświęconej metodologii historii pisał, że „nauka ta powinna rzetelnie przedstawić dzieje nadające kierunek czynom ludzi”. Jako autor stawiający sobie cele dydaktyczne zwracał dużą uwagę na chronologię, genealogię i etymologię, dając czytelnikowi zwięzły zasób elementarnej wiedzy o zwiedzanym kraju.

Natomiast jako popularyzator wiedzy starał się przekazywać odbiorcy dzieła informacje kompletne i opracowane przystępnie nawet dla człowieka o małym wykształceniu. Pisał o tym trudzie twórcy - kompilatora w Przedmowie drugiej do czytelnika idyjoty, nieuczonego, mniej rozeznanego a cenzora wielkiego. Owymi cenzorami byli prostacy, ludzie mało wykształceni, a surowi w ocenie Nowych Aten. Ci nie rozumieli, jak wielką pracę wykonał ksiądz Chmielowski. Uważali, że „nie sztuka z książek wypisać, co ładne”. Odpowiadając na ten zarzut uczony odsłonił tajemnice swego warsztatu, wytłumaczył, na czym polegała jego praca. Nie było łatwo

Wziąć sobie nowe thema, porządek, osnowę, Dobierać sensów, słówek, czyniąc rzeczy nowe [podkr. M. W.] Nie pisać słowo w słowo (...).

Uczony nie jest tu odkrywcą nowych zjawisk, ale tworzy „rzeczy” nowe w sensie redagowania własnego tekstu, wykonuje odpowiedzialną i niewdzięczną pracę. Rzetelny trud badacza, kreatora „nowej”, „podręcznej” wiedzy o świecie nie jest należycie ceniony. Studia

12 A. F. Grabski, Historyzm sarmacki a historyzm oświecenia, „Przegląd Humanistyczny” 1972 nr 5, s. 5. 
przygotowawcze, gromadzenie materiału są niezwykle czasochłonne. Ponadto autor musi liczyć się z „manijerą”, metodą, stylem pisania.

Że zaś rzucam często [po] łacinie? Nie dziwuj się, bo to do mojej należy proprie [szczególnie] Akademiji.

(Do czytelnika)

Chmielowski tłumaczy się ze stosowania wtrętów łacińskich, z piętnowanego wówczas makaronizowania. „Mowa mieszana”, by użyć słów Grzegorza Knapskiego, była wówczas bardzo popularna z jednej strony, zwalczana zaś z drugiej strony. Ogół szlachecki uwielbiał wstawki łacińskie w swych oracjach i innych wypowiedziach, z biegiem czasu stało się to nieznośną manierą, przyczyną zepsucia stylu, dlatego też uczeni (Knapski, później Konarski) byli za usuwaniem makaronizmów z polskich tekstów. Jednakże sam Knapski znajdował uzasadnienie dla wtrętów łacińskich, gdy nie pojawiały się one zbyt często, a stanowiły ozdobę wypowiedzi, przytoczenie czyjejś myśli w oryginale. Taką taktykę stosowało wielu wybitnych pisarzy z Justem Lipsjuszem (1547-1606) na czele.

W baroku utarło się przekonanie, że styl lipsjański stał się niejako pretekstem dla praktyki makaronizowania. Styl uczonego Belga odznaczal się sentencjonalnością, częstym stosowaniem własnych maksym lub zaczerpniętych z cudzych dzieł cytatów. Podobnie autor Nowvych Aten stosuje liczne zwroty przysłowiowe, sentencje polskie, częściej jednak łacińskie, gdyż jest to język nauki, gdyż pracę swą kieruje ku ludziom wykształconym, obytym z mową Cycerona, a nie ku „formalnym idyjotom”, i wreszcie dlatego, że wtręty łacińskic stanowią okrasę dzieła pisanego po polsku, ponieważ polszczyzna „skąpa jest w słowa wyboryczne i w słowa scyjentificzne". Tak więc styl makaroniczy to kolejny czynnik łączący Chmielowskiego ze światem barokowej kultury i nauki.

Praca to jest od deski czytać aż do drugiej,

Czasem i punkt się nie zda $\mathrm{z}$ tak legendy drugiej (...).

(Przedmowadruga...)

Zatem trzeba dokonać selekcji materiału, kierować się w jego doborze krytycyzmem. Chmielowski i w tym względzie jest uczonym barokowym, korzystał bowiem z dzieł i doświadczenia badawczego Athanasiusa Kirchera (1602-1680), jezuity niemieckiego, uczonego znanego w całej Europie, fizyka, geologa objawiającego także zainteresowanie matematyką i filologią. W Nowych Atenach znalazł się jego biogram.

Athanasius Kircher rodem z Fuldy, miasta Buchoniji w Niemczech, zakonu Societatis Jesu, mąż wielkiego i ciekawego rozumu, wszystkich starożytności compendium, filozof, matematyk, teolog, w językach oryjentalnych i europejskich wielu bardzo biegły, rzeczy naturalnych i niedościgłych badacz ad fundum [dogłębnie] penetrujący. Ksiąg wiele popisał w różnych, osobliwie matematycznych materyjach. Ja mam sobie za szczęście, żem czytał jego [1.] Mundum 
subterraneum, in folio wielką księgę, 2. Arcam Noe, 3. Turrim Babel (...) i z tych jego ksiąg wielem się nauczył, jako często cytuję tu w moich Atenach. Uczył matematyki w Wircemburgu, Awenionie, w Rzymie, gdzie też umarł (t. III, s. 652).

Twórca ten posługiwał się takimi metodami badawczymi, które i Chmielowskiemu wydały się odpowiednim narzędziem poznania naukowego. Oto co o warsztacie Kirchera mówi wybitny znawca encyklopedyzmu XVII w.:

Pisarz gotów jest przemierzyć wszystkie drogi i ścieżki przebyte już przez starożytnych i „nowożytnych”, obdarzony nienasyconą ciekawością i zapewne nie tak łatwowierny i bezbronny, jak to ukazywały niektóre schematyczne wizerunki, intelektualista zawsze doskonale poinformowany i dbający o zebranie możliwie najobszerniejszego materiału dotyczącego wszystkich sztuk, nauk i technik, a ponadto wszystkich cywilizacji, kultur i tradycji poznanych i napotkanych przez jego niestrudzonych konfratrów $(. . .)^{13}$.

Intelektualista zawsze dobrze poinformowany i dbający o zebranie materiału pełnego, umożliwiającego opracowanie dzieła pansoficznego, musiał kierować się w selekcji tegoż materiału krytycyzmem i obiektywizmem. Gdy przedstawiał poglądy nie całkiem z sobą zgodne, czasem nawet sprzeczne, referował je beznamiętnie, nie zajmując wyraźnego stanowiska, nie rozstrzygając ostatecznie kwestii. Zachowywał chwalebny obiektywizm, jak w wypadku biogramu Kopernika:

Nicolaus Copernicus z Torunia polskiego, Polsko-Prusak, kanonik warmiński. Uczył się w Rzymie matematyki. Powróciwszy do ojczyzny cały się udał do gwiazdarskiej nauki. Obserwacyje jednak swoje matematyczne aż w 36 lat na wielkie godnych ludzi prośby wydał na świat, Pawłowi III papieżowi je przypisawszy. Trzymał takowe sistema, że okrąg ziemi koło słońca swoj bieg odprawuje i obrót, ktorą sentencyją zakazała była Stolica Apostolska, iż przeciw Pismu Świętemu. Ale tych wieków chwytają się jej nicktórzy. Umarł roku 1543 (t. III, s. 608).

Uczony, zarazem kapłan katolicki, zwięźle i rzeczowo, bez stronniczości, przedstawił sylwetkę i dzieło Kopernika, które, jak wiadomo, znalazło się na indeksie ksiąg zakazanych. Dodał, że „sentencyja” renesansowego astronoma znajduje zwolenników w dobie powstania Nowych Aten.

Bywają jednak i takie miejsca w encyklopedii, gdzie kapłan wziął górę nad uczonym. W tomie I tytuł 23 brzmi: Stońce między umbrami jasne, lilija między ciemiem, szkopuł między fluktami albo wiara śvięta katolicka... Chmielowski nie wcielał się $\mathrm{w}$ teologa, ale „niektóre necessaria curiosa [tutaj: potrzebniejsze szczegóły] do tejże wiary się regulujące światu podał”.

13 C. Vasoli, op. cit., s. 29. 
Między innymi z naciskiem podkreślił, że tylko katolicyzm jest wyznaniem gwarantującym zbawienie. Nie miał zrozumienia dla odszczepieńców i heretyków, bo i nie mógł wtedy być tolerancyjny w dzisiejszym rozumieniu.

Niech trzymaja policyjej i libertyni, że człowiek w każdej wierze może być zbawiony, ale ci wszyscy errant [błądza] aż do pickła, ktorzy tak putant [sądzą], gdyż wyraźne są słowa ś. Pawła do Efezów, że jest una fides, unum baptisma [jedna wiara, jeden chrzest - Ef 4,5].

(t. I, s. 1008)

Jednakże ten odosobniony przykład nie może zmienić oceny warsztatu naukowego Chmielowskiego w aspekcie jego obiektywizmu i krytycyzmu. Obok wymienionych autor encyklopedii często stosował także kryterium zdrowego rozsądku, czasem wspicrał się również doświadczeniem. Pisząc o alchemii, o dążcniu uczonych do uzyskania złota „przez pewny sekret" nie umiał się jednoznacznie wypowiedzieć, czy było to możliwe. Natomiast zdrowy rozsądek nakazywał uznać, że było to szkodliwe:

Ta ars [sztuka] czy-li dabilis et possibilis [wykonalna i możliwa], jedni cale negant [przeczą], drudzy widzący i słyszący ex oculatis testibus [od naocznych świadków] prawdziwe dokumenta, affirmant [potwierdzają]. Mnie należy media sapere et sequi [postępować środkiem], ani negować ani twierdzić, tylko to widzieć, że Kościoł Boży hanc artem [sztukę tę] cale zakazal, z racyi wielu bogatych ludzi, do ostatniego przychodzących ubóstwa, ktorych auri sacra fames [przeklęta żądza złota - Vergilius, Aeneis III, 57] czy-li cickawość z worka ogołociwszy, do torby przyprowadziła.

Chmielowski chętnie posługiwał się eksperymentem jako narz̨̨dziem uwiarygodnienia podawanych faktów, porad itp. Czasem jego dzieło miało wiele wspólnego z kalendarzami gospodarskimi. W takich miejscach encyklopedii widać szczególną troskę autora, aby nadać jej charakter pragmatyczny i utylitarny, aby zamieszczone rady były sprawdzone, a zatem skuteczne.

Czym stracić brodawki? Weź liścia figowego, nim nacieraj brodawki, zginą, byleś też same liście w ziemię wkopał. Serce gołębia, nim brodawki ścierając, toż sprawuje, według Mizalda autora. Ale ja doświadczyłem, że ziele te, co koło murów starych rośnie, żółto kwitnic, a zerwawszy go żółte z siebie sączy mleko, tym mlekiem jeśli raz-drugi posmarujesz brodawkę, trochę ją zraniwszy zginie; strzec się zaś potrzcba, aby krew ta nie tknçła ciała na innym miejscu, bo tam inna urodzi się brodawka.

(t. III, s. 513) 
Uczony podał więc trzy możliwości leczenia, ale tylko jedną sprawdził poprzez doświadczenie i ta jest najbardziej godna polecenia.

Zbierając dotychczasowe refleksje o warsztacie badawczym Benedykta Chmielowskiego wypada uznać, że u progu polskiego oświecenia ogłosił swe opus vitae oświecony Sarmata, uczony o barokowym poglądzie na świat i typowy reprezentant barokowego encyklopedyzmu. Świadczą o tym: obecna w jego dziele idea pansofizmu, systematyczny układ encyklopedii, barokowa koncepcja imitacji, metoda kompilacji (stare przedstawione po nowemu), barokowa koncepcja popularyzacji wiedzy, dydaktyczny i utylitarny cel kompendium, historyzm sarmacki, barokowy smak estetyczny, w tym makaronizowanie, a także potrydencka wizja świata. Jest przecież pisarzem katolickim. Podstawowy cel jego pisania to maior gloria Dei. Ostentacyjnie demonstruje punkt widzenia kapłana katolickiego, a jako autor encyklopedii troszczy się przede wszystkim o zebranie argumentów, o przygotowanie narzędzi pomocnych bądź w budowaniu, bądź w obronie „sakralnej wizji świata, którego centrum zdaje się stanowić doczesna i świecka egzaltacja monarchii duchowej" ${ }^{14}$.

14 Tamże, s. 30. 